\title{
Soda Pulping of Torch Ginger Stem: Promising Source of Nonwood-Based Cellulose ${ }^{1}$
}

\author{
Herman Marius ZENDRATO ${ }^{2} \cdot$ Yunita Shinta DEVI $^{2}$ • \\ Nanang MASRUCHIN ${ }^{3} \cdot$ Nyoman J. WISTARA (D) ${ }^{2, \dagger}$
}

\begin{abstract}
Torch ginger (Etlingera elatior Jack) is a potential source of lignocellulose material for various derivative products. This study aims to determine the chemical components, ratio of syringyl to guaiacyl units (S/G) in lignin, and crystallinity of the biomass of torch ginger. The effects of soda pulping on the chemical characteristics of torch ginger pulp were also studied. Pulping of the chips was conducted with active alkali of $15 \%, 20 \%$, and $25 \%$ and a Liquor-to-Wood $(\mathrm{L} / \mathrm{W})$ ratio of $4: 1,5: 1$, and $6: 1$. The impregnation and pulping times at maximum temperature $\left(170^{\circ} \mathrm{C}\right)$ were 120 and $90 \mathrm{~min}$, respectively. To assess the effect of treatments on the properties of pulping, a two-factorial experimental design was applied. Results showed that the content of $\alpha$-cellulose and hemicellulose in the torch ginger was $48.48 \%$ and $31.50 \%$, respectively, with an $\mathrm{S} / \mathrm{G}$ ratio of 0.70 in lignin. Soda pulping changed the crystalline structure of the biomass from triclinic to monoclinic. Active alkali, L/W ratio, and interactions considerably influenced the observed responses. The degree of delignification increased with an increase in the loading of active alkali, which lead to a decrease in the kappa number of the pulp. An active alkali content of $25 \%$ and an $\mathrm{L} / \mathrm{W}$ ratio of $6: 1$ resulted in the highest delignification selectivity with a kappa number of 2.78 and a yield of $24 \%$. Given its cellulose content and ease of pulping, torch ginger can be a potential raw material for derivative products that require delignification as pretreatment. However, the increase in cellulose crystallinity should be considered when converting torch ginger to bioethanol.
\end{abstract}

Keywords: Etlingera elatior, torch ginger, L/W ratio, S/G ratio, soda pulping

\section{INTRODUCTION}

Lignocellulosic material is a versatile natural product convertible to various derivatives such as biofuel, chemicals, pulp and paper products, animal feedstocks, and composite polymers (Iqbal et al., 2013). Wood is the primary source of cellulose. However, their productions are insufficient to satisfy the increasing global demand. FAO (2009), for example, predicted that in 2030, in Asia and the Pacific alone, the consumption and production of sawn wood will reach 113 million $\mathrm{m}^{3}$ and approximately 97 million $\mathrm{m}^{3}$, respectively. Furthermore, approximately 747 million $\mathrm{m}^{3}$ of wood for paper and paperboard will be needed, with only 743 million $\mathrm{m}^{3}$ of production. It can be seen that

\footnotetext{
${ }^{1}$ Date Received March 13, 2021, Date Accepted May 24, 2021

${ }^{2}$ Department of Forest Products, Faculty of Forestry and Environment, IPB University, Bogor 16680, Indonesia

${ }^{3}$ Research Center for Biomaterials, Indonesia Institute of Sciences (LIPI), Bogor 16911, Indonesia

$\dagger$ Corresponding author: Nyoman J. WISTARA (e-mail: nwistara@apps.ipb.ac.id, ORCID: 0000-0002-7093-9385)
} 
the production capacity of wood tends to be lower than that of the consumption. Wood production of Indonesia is even worse, where during 2008 - 2018, only $5-7$ million $\mathrm{m}^{3}$ wood was produced from natural forest and in an average of 27 million $\mathrm{m}^{3}$ from plantation forest (APHI, 2019). Wood production was far below the demand for structural, furniture, and pulp and paper purposes. Therefore, endeavors for exploring new lignocellulosic sources are paramount, mainly with the increasing trend of using environmentally friendly renewable biobased products in the future. The effort of using fast-growing wood species (Wistara et al., 2015), short rotation coppice wood (Jo et al., 2019), and non-wood plants such as mengkuang (Yanti et al., 2019), kapok balsa (Purnawati et al., 2018), and bamboos (Park et al., 2018) as new sources of biomaterials have been carried out.

Among various lignocellulosic sources, torch ginger (Etlingera elatior (Jack) RM Smith) grows well in many areas of Indonesia. It is a native plant of Sumatra and can be found in many South East Asia countries (Maimulyanti and Prihadi, 2015). Torch ginger stem is a good source of cellulose (Foster, 2011) and can be utilized for a high-quality painting paper raw material (Shafaei et al., 2011). The preparation of essential oils (Jaafar et al., 2007), anticancer properties (Mai et al., 2009), and flavonoids analysis (Chang et al., 2012) of the leaves, stems, flowers, and rhizomes of the torch ginger have also been studied. The extraction waste of the torch ginger is a potential source of renewable cellulose. Non-wood cellulose is currently getting a more significant consideration for the production of nano cellulose (Pennells et al., 2020), and bioethanol due to sugary and starchy material bioethanol is considered very unsafe to food stock security (Bušić et al., 2018). Therefore, exploration of cellulose sources for the raw material of bioethanol is paramount, and torch ginger can be a vital source of cellulose since it can be cultivated through an agroforestry system under the extensively develops plantation forests.

From the quality of its cellulose, torch ginger could also be a potential raw material for nano cellulose-based products and bioethanol production. In nano cellulose production, the knowledge of the chemical composition (cellulose, hemicellulose, and lignin) and physical properties (crystallinity) of the biomass is essential. Hemicellulose content was found to influence the mechanical extraction of nano cellulose (Iwamoto et al., 2008), and lignin content influenced the strength and flexibility properties of PLA-LCNF based composites (Wang et al., 2018). Furthermore, the crystalline nature of the lignocellulosic raw material is considered an essential influencing factor in producing nano cellulose crystals (Moreno et al., 2018). Biomass with a higher cellulose content potentially produces a higher amount of ethanol (Kikas et al., 2014) since cellulose is the source of glucose, a fermentable reducing sugar. Even though some investigated fermenters tolerate the presence of hemicellulose in bioethanol production (Ji et al., 2012), it must be removed in the preparation of nano cellulose by acid hydrolysis processes (Moreno et al., 2018). Despite its potential, the complex structure of lignocellulosic materials leads to its recalcitrant nature to chemical reaction and biological fermentation (Min et al., 2013; Li et al., 2011) and become the main factor influencing the efficiency of its conversion into bioethanol (Hadar, 2013). The cellulose crystalline properties (Bušić et al., 2018) and the lignin structure (Li et al., 2016) make the biomass recalcitrant when converted into bioethanol and cellulose nanocrystal. Even though all cellulose has the same polymer structure at a molecular level, its supramolecular and morphological structure could vary depending on the sources. Therefore, the structural analysis of cellulose from various biomass sources needs to be done to convert the cellulose into its derivative products properly.

Pretreatment on cellulose materials is usually required before converting them into their derivative products. Pretreatment removes part of lignin, reducing cellulose 
crystallinity and increasing biomass porosity (Maurya et al., 2015). Alkaline pretreatment is the most commonly used for biomass pretreatment before conversion into various derivative products. Alkali, mainly sodium hydroxide, is a suitable swelling agent for cellulose and the principal delignifying agent in alkaline pulping methods. The composition of syringyl and guaiacyl lignin influence the ease of delignification under alkaline condition (Xiao et al., 2012). Alkali concentration is also considered in maximizing the delignification and digestibility of biomass (Chen et al., 2013). The conversion efficiency of corn stalk (Zhu et al., 2010), bagasse (Maryana et al., 2014), and pinewood (Salehian et al., 2013) have been proven successfully improved with alkaline $(\mathrm{NaOH})$ pretreatment.

The present experiment was intended to identify the chemical compositions, $\mathrm{S} / \mathrm{G}$ lignin ratio, and crystallinity of the torch ginger stem. The influence of alkaline pretreatment on the characteristic of torch ginger pulp was also studied. The study is expected to provide information regarding the appropriate use of torch ginger biomass for valuable derivative products.

\section{MATERIALS and METHODS}

The outline of the present research is depicted in Fig. 1. The pseudostem of torch ginger was initially chipped into 2-4 cm length with the thickness of 3 $-5 \mathrm{~mm}$ and then air-dried. However, upon air-drying,

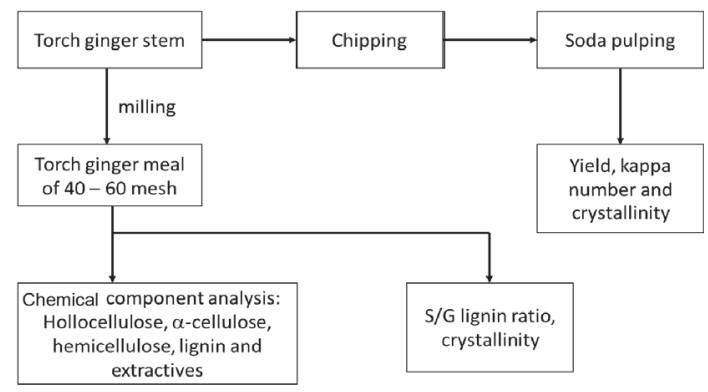

Fig. 1. Experimental outline. the pseudostem chips were naturally split into $2-3 \mathrm{~mm}$ layers. Therefore, the size of the chips during the pulping process was $2-3 \mathrm{~mm}$ thick and $2-4 \mathrm{~cm}$ long. A portion of the air-dried chips was milled and sieved to obtain a torch ginger meal of $40-60$ mesh size for chemical analysis. Sample preparation for the chemical component analysis was carried out following the standard procedure of TAPPI T $257 \mathrm{sp}-14$.

\subsection{Chemical component}

Ethanol-benzene soluble extractives and Klason lignin of the torch ginger stem were determined following TAPPI T 204 om-88 and TAPPI T 222 om-88 standard procedures, respectively. Holocellulose and $\alpha$ - cellulose were determined following the procedure of Browning (1967). Hemicellulose content was calculated by the difference between holocellulose and $\alpha$-cellulose content.

\section{2. $S / G$ lignin ratio}

S/G lignin ratio was determined based on the FTIR method developed by Faix et al.(1991) using Bucher Tensor 37 FTIR Spectroscopy. S/G ratio was calculated based on the ratio between spectrum peak area of syringyl lignin unit and guaiacyl lignin unit (wavenumber of $1462 \mathrm{~cm}^{-1} / 1510 \mathrm{~cm}^{-1}$ ). FTIR spectra of the samples were procured by the $\mathrm{KBr}$ method. In the method, 2 $\mathrm{mg}$ of torch ginger meal were thoroughly mixed with $200 \mathrm{mg} \mathrm{KBr}$. The mixture was formed into a pellet in a pellet die using $80 \mathrm{~N}$ of pressure for $2 \mathrm{~min}$. The pellet was then vacuumed for $5 \mathrm{~min}$. The spectra were collected from 32 scannings at the resolution of $4 \mathrm{~cm}^{-1}$ in the wavenumber of $4000-400 \mathrm{~cm}^{-1}$.

\subsection{Crystallinity}

The crystallinity of the torch ginger and its pulp were determined using Shimadzu XRD 7000 X-Ray Diffractometer Maxima $\mathrm{X}$ with the $\mathrm{X}$-ray source of copper $(\mathrm{Cu})$. The 
measurement was carried out at $40 \mathrm{kV}$ and $30 \mathrm{~mA}$ electric current with scanning speed $2 \%$ min and scanning angle of $10-40^{\circ}$. Crystallite structure was determined by calculating the $\mathrm{Z}$ value following Wada and Okano (2001), in which: $Z=1693 \mathrm{~d}_{1}(\mathrm{~nm})-902 \mathrm{~d}_{2}$ (nm) -549 ( $Z=$ crystal structure, $d_{1}=$ peak distance of $0.59-0.62$ $\mathrm{nm}, \mathrm{d}_{2}=$ peak distance of $0.52-0.55 \mathrm{~nm}$.

\subsection{Soda Pulping}

Soda pulping of torch ginger stem was carried out with different active alkali as indicated in Table 1. All batches of the pulping process were performed with an equal $\mathrm{H}$-factor of 1300 , the total cooking time of $210 \mathrm{~min}$ (120 min impregnation and $90 \mathrm{~min}$ at maximum temperature of $170{ }^{\circ} \mathrm{C}$ ). The kappa number of pulps was determined following TAPPI T236 OM-85. The screened yield of pulping, the degree of delignification, and the delignification selectivity were, respectively, calculated following the formulae of:

Pulping yield $=\frac{\text { Oven dry weight of pulp (g) }}{\text { Oven dry weight of chips }} \times 100 \%$

Delignification degree $=\frac{\text { Total lignin in chips }- \text { residual lignin in pulp }}{\text { Total lignin in chips }} \times 100 \%$

Delignification selectivity $=\frac{\text { Carbohydrates content of pulp }(\mathrm{g})}{\text { Lignin content of pulp }(\mathrm{g})} \times 100 \%$

\subsection{Data analysis}

A factorial complete random design with two factors, i.e., active alkali (with three levels of $15 \%, 20 \%$, and $25 \%$ ) and L/W ratio (with three levels of $4: 1,5: 1$, and $6: 1$ ), was used to analyze the resulting experimental data. The data were procured in three replicates. Duncan's multiple range test was further applied to examine the influence of treatments.

\section{RESULTS and DISCUSSION}

\subsection{Chemical components}

Results showed that the content of extractives, Klason lignin, $\alpha$-cellulose and hemicellulose of torch ginger stem was $6.33 \pm 0.00 \%, 18.30 \pm 0.24 \%, 48.48$ $\pm 0.65 \%$, and $31.50 \pm 0.96 \%$, respectively. Cellulose content is an important parameter for using biomass as the raw material of fiber and its derivative products. Lignocellulosic material with higher than $34 \%$ cellulose content is considered a promising raw material of pulp and paper products (Nieschlag et al., 1960). Therefore, torch ginger stem with $48 \%$ cellulose is a potential raw material for pulp and paper production. Pulping of torch ginger stem would result in a high yield considering that, in general, the pulping yield is positively correlated to the holocellulose and $\alpha$-cellu-

Table 1. Soda pulping conditions of torch ginger stem

\begin{tabular}{|c|c|c|c|c|}
\hline Active alkali (\%) & $\mathrm{L} / \mathrm{W}$ ratio & Oven dry weight of chips (g) & Maximum temperature $\left({ }^{\circ} \mathrm{C}\right)$ & Cooking time $(\mathrm{min})$ \\
\hline \multirow{3}{*}{15} & $4: 1$ & 100 & 170 & 210 \\
\hline & $5: 1$ & 100 & 170 & 210 \\
\hline & $6: 1$ & 100 & 170 & 210 \\
\hline \multirow{3}{*}{20} & $4: 1$ & 100 & 170 & 210 \\
\hline & $5: 1$ & 100 & 170 & 210 \\
\hline & $6: 1$ & 100 & 170 & 210 \\
\hline \multirow{3}{*}{25} & $4: 1$ & 100 & 170 & 210 \\
\hline & $5: 1$ & 100 & 170 & 210 \\
\hline & $6: 1$ & 100 & 170 & 210 \\
\hline
\end{tabular}


lose content (Moradbak et al., 2016).

The lignin content of torch ginger stem (18.30\%) was relatively lower than those commonly found in woody biomass (Wistara et al., 2015; Ruiz-Aquino et al., 2019; Jo et al., 2019). Delignification in the pulping process requires a high amount of energy and chemicals (Ververis et al., 2004). Thus lignin is an undesirable chemical component mainly in chemical pulp production. However, at a lignin content of below $20 \%$, high reducing sugar yield can be achieved from the hydrolysis process without pretreating the biomass (Studer et al., 2011). Even though Jang et al.(2017) found that mechanical means used in the preparation of nano cellulose are independent of the lignin content, carboxylated nano cellulose can only tolerate lignin content below 24\% (Khanjanzadeh and Park 2020).

\section{2. $S / G$ lignin ratio}

S/G lignin ratio was determined based on the FTIR method, and the measurement results are listed in Table 2. Studer et al.(2011) classified the $\mathrm{S} / \mathrm{G}$ ratio as low when the value is less than two and high for the $\mathrm{S} / \mathrm{G}$ ratio of 2 or higher. The $\mathrm{S} / \mathrm{G}$ ratio of torch ginger stem was 0.70 , higher than the $\mathrm{S} / \mathrm{G}$ ratio of its pulp. At lower alkali charge (15\% active alkali), the increase of $\mathrm{L} / \mathrm{W}$ ratio tended to increase the $\mathrm{S} / \mathrm{G}$ ratio. Meanwhile, at higher alkali charges $(20 \%$ and $25 \%$ active alkali), increasing the $\mathrm{L} / \mathrm{W}$ ratio decreased the $\mathrm{S} / \mathrm{G}$ ratio. Bulk delignification at a low alkali charge decreases the alkali concentration at the end of cooking, and with a high alkali charge, a better alkali profiling (alkali concentration nearly constant at all stage of cooking) is achieved (Gustavsson 2007). Therefore, the increase and decrease of $\mathrm{S} / \mathrm{G}$ ratio, respectively, at low and high alkali charge with increasing the $\mathrm{L} / \mathrm{W}$ ratio were related to the liquor's alkali concentration. The decrease of the $S / G$ ratio with increasing alkali charge could be problematic when alkali pretreatment is carried out for bioethanol production. The increase of the $\mathrm{S} / \mathrm{G}$ ratio decreases the reducing sugar production of Populus trichocarpa wood (Yoo et al., 2017).

The higher rate of syringyl lignin degradation compared to guaiacyl lignin brought about the decrease of the $\mathrm{S} / \mathrm{G}$ ratio of pulps by increasing the active alkali charge. It can be seen from the change in syringyl and guaiacyl units lignin upon the change of $\mathrm{L} / \mathrm{W}$ ratio shown by Table 2 . At $15 \%$ active alkali, with the $\mathrm{L} / \mathrm{W}$ ratio of $4: 1$ and $6: 1$, syringyl lignin reduction reached the value of $64 \%$ and $39 \%$, respectively. Meanwhile, the guaiacyl lignin unit at $\mathrm{L} / \mathrm{W}$ ratio of $4: 1$ and $6: 1$ was only reduced $5 \%$ and even increased about $15 \%$, respectively. The increase of guaiacyl unit lignin has not been understood yet. With a higher alkali charge (e.g., 25\% active alkali), either using an $\mathrm{L} / \mathrm{W}$ ratio of

Table 2. The $\mathrm{S} / \mathrm{G}$ lignin ratio of torch ginger stem

\begin{tabular}{|c|c|c|c|c|}
\hline \multicolumn{2}{|c|}{ Treatment } & \multirow{2}{*}{ Syringyl unit } & \multirow{2}{*}{ Guaiacyl unit } & \multirow{2}{*}{$\mathrm{S} / \mathrm{G}$ ratio } \\
\hline Active alkali $(\%)$ & $\mathrm{L} / \mathrm{W}$ ratio & & & \\
\hline Control (torch ginger stem) & & 0.2722 & 0.3875 & 0.70 \\
\hline \multirow{2}{*}{15} & $4: 1$ & 0.0969 & 0.3680 & 0.26 \\
\hline & $6: 1$ & 0.1663 & 0.4472 & 0.37 \\
\hline \multirow{2}{*}{20} & $4: 1$ & 0.0867 & 0.3522 & 0.25 \\
\hline & $6: 1$ & 0.0621 & 0.2694 & 0.23 \\
\hline \multirow{2}{*}{25} & $4: 1$ & 0.0256 & 0.2009 & 0.13 \\
\hline & $6: 1$ & 0.0232 & 0.2041 & 0.11 \\
\hline
\end{tabular}


$4: 1$ or $6: 1$, the syringyl lignin unit reduced $91 \%$. Moreover, a $48 \%$ and $47 \%$ reduction in guaiacyl lignin unit was found, respectively, for the L/W ratio of $4: 1$ and $6: 1$. These data indicated that the syringyl lignin unit was much more susceptible to alkaline than the guaiacyl lignin unit. The present finding was in agreement with the statement of Marques et al.(2010) that delignification proceeds better at higher syringyl content due to the syringyl lignin is relatively less branched and having a lower condensation degree compared to that of guaiacyl lignin. Furthermore, syringyl lignin contains higher amounts of $\beta$-O-4 linkages that are simpler to be cleaved than those present in guaiacyl lignin (Tsutsumi et al., 1995). As a result, pulping of woody biomass with a higher amount of syringyl lignin requires fewer chemicals and possibly capable of preventing fiber degradation for better pulp strength (Santos et al., 2013).

\subsection{The crystallinity of torch ginger stem and pulps}

The crystallinity of torch ginger stem was $41.72 \%$, lower than the crystallinity of pulps that tended to increase with increasing active alkali (Table 3). The same trend has been reported by Abraham et al.(2011), Jiao and Xiong (2014), and Suryanto et al.(2014), respectively, for the pulping of banana leaves, ramie, and bamboo.
Degradation of amorphous components (such as lignin and hemicellulose) during pulping is the origin of increasing crystallinity (Rahnama et al., 2013). However, redeposition of the degradations products of the amorphous component at a lower $\mathrm{L} / \mathrm{W}$ ratio (Gustavsson 2007) could otherwise reduce the crystallinity of the pulps. Redeposition of the degradation products is avoided in a higher $\mathrm{L} / \mathrm{W}$ ratio. Therefore, pulp crystallinity increased when pulping is carried out at a higher active alkali and $\mathrm{L} / \mathrm{W}$ ratio. In alkaline pulping, increasing the crystallinity of pulps could also occur by random hydrolysis and peeling reaction of the less ordered cellulose (Gümüskaya et al., 2003). Following the present results, where at lower active alkali and L/W ratio, lower crystallinity of pulp was obtained. Meanwhile, higher active alkali (25\%) and higher L/W ratio resulted in a higher pulp crystallinity.

Table 3 indicates that the torch ginger stem retained a triclinic crystal structure $\left(\mathrm{I}_{\alpha}\right)$. Except for pulping with $15 \%$ active alkali at $\mathrm{L} / \mathrm{W}$ of $4: 1$ and active alkali of $20 \%$ at $\mathrm{L} / \mathrm{W}$ of $6: 1$, the crystal structure was transformed into a monoclinic $\left(\mathrm{I}_{\beta}\right)$ upon pulping processes. The heating process transforms the triclinic structure into the monoclinic structure (Matthews, 2011). The triclinic structure is thermodynamically more stable (Wada et al., 2010) and more reactive to hydrolysis (Isroi et al., 2012).

Table 3. The crystallinity of torch ginger stem and its pulps

\begin{tabular}{|c|c|c|c|c|}
\hline \multicolumn{2}{|l|}{ Treatment } & \multirow{2}{*}{ Crystallinity (\%) } & \multirow{2}{*}{$\mathrm{z}$} & \multirow{2}{*}{ Allomorph structure } \\
\hline Active alkali & $\mathrm{L} / \mathrm{W}$ ratio & & & \\
\hline Control (torch ginger stem) & & 41.72 & 3.0982 & $\mathrm{I}_{\alpha}$ \\
\hline \multirow{2}{*}{$15 \%$} & $4: 1$ & 50.56 & 19.7927 & $\mathrm{I}_{\alpha}$ \\
\hline & $6: 1$ & 54.59 & -69.4079 & $\mathrm{I}_{\beta}$ \\
\hline \multirow{2}{*}{$20 \%$} & $4: 1$ & 62.41 & -56.5069 & $\mathrm{I}_{\beta}$ \\
\hline & $6: 1$ & 59.62 & 11.0735 & $\mathrm{I}_{\alpha}$ \\
\hline \multirow{2}{*}{$25 \%$} & $4: 1$ & 58.84 & -47.4957 & $\mathrm{I}_{\beta}$ \\
\hline & $6: 1$ & 62.53 & -62.9924 & $\mathrm{I}_{\beta}$ \\
\hline
\end{tabular}

Note: $\mathrm{I}_{\alpha}=$ Triclinic, $\mathrm{I}_{\beta}=$ Monoclinic. 


\subsection{Alkaline pulping of the torch ginger stem}

Table 4 indicates the influence of active alkali and $\mathrm{L} / \mathrm{W}$ ratio on the pulping yield, kappa number of pulps, Klason lignin, delignification degree, and delignification selectivity. It shows that the interaction between active alkali and L/W ratio very significantly influenced the kappa number of pulps, pulping yield, degree of delignification, Klason lignin, and delignification selectivity.

\subsection{The degree of delignification and Kappa number}

The degree of delignification increased with increasing active alkali (Fig. 2). It was pulping with $25 \%$

Table 4. The ANOVA summary of the pulping data

\begin{tabular}{lccc}
\hline & \multicolumn{3}{c}{ Factors } \\
\cline { 2 - 4 } Response & $\begin{array}{c}\text { Active alkali } \\
\text { (A) }\end{array}$ & $\begin{array}{c}\text { L/W ratio } \\
\text { (B) }\end{array}$ & $\begin{array}{c}\text { Interaction of } \\
\text { A and B }\end{array}$ \\
\hline \hline $\begin{array}{l}\text { Kappa number } \\
\text { Degree of } \\
\text { delignification }\end{array}$ & $0.000^{* *}$ & $0.014^{*}$ & $0.000^{* *}$ \\
$\begin{array}{l}\text { Klason lignin } \\
\text { Delignification } \\
\text { selectivity }\end{array}$ & $0.000^{* *}$ & $0.014^{*}$ & $0.000^{* *}$ \\
Pulping yield & $0.000^{* *}$ & $0.000^{* *}$ & $0.000^{* *}$ \\
\hline
\end{tabular}

Note: *: significant and

**: strongly significant at the confident level of $95 \%$ active alkali at an $\mathrm{L} / \mathrm{W}$ ratio of $6: 1$ resulted in the highest degree of delignification. Active alkali is related to the hydroxide ion concentration in the pulping solution. Lignin degradation increases at a higher hydroxide ion concentration. Sodium hydroxide is an excellent swelling agent for lignocellulosic materials that facilitates the penetration of pulping liquor into the chips (Li et al., 2014).

Delignification degree influences the residual lignin in pulp measured as kappa number. An increasing degree of delignification tends to decrease the kappa number, e.g., as found in the case of jabon wood pulping (Wistara et al., 2015). At lower alkaline concentration (15\%), the degree of delignification decreased with increasing $\mathrm{L} / \mathrm{W}$ ratio, which was in contrast to using a higher alkaline concentration (25\%). At $25 \%$ active alkali, increasing the $\mathrm{L} / \mathrm{W}$ ratio increased the degree of delignification and decreased the kappa number of pulps. At an L/W ratio of 6:1, a low kappa number of 2.78 was obtained. Abdel-Aal (2013) found a $6 \%$ increase in active alkali capable of decreasing a seven-point kappa number.

\subsection{Delignification selectivity}

Results showed that the delignification selectivity of torch ginger stem soda pulping increased with the active alkali concentration. Duncan's multiple range test
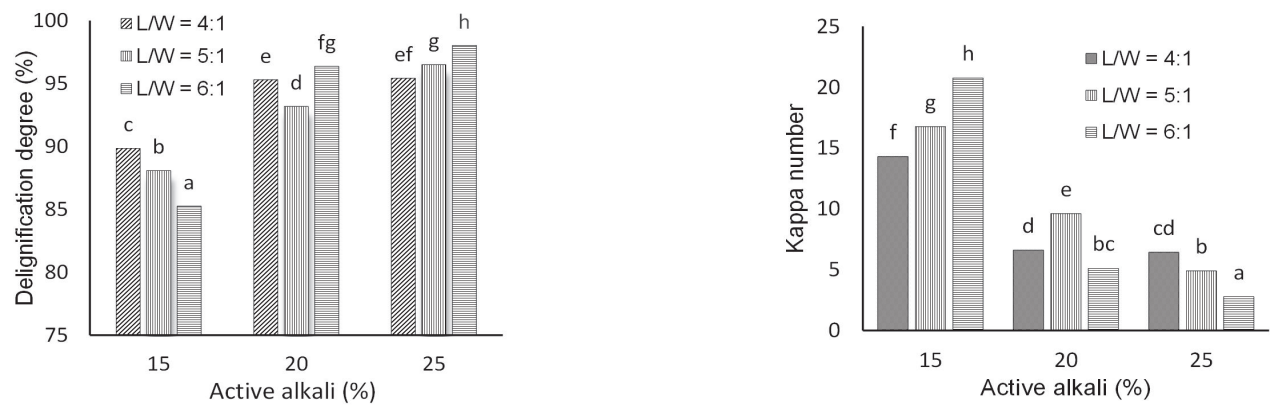

Fig. 2. The effect of active alkali and $\mathrm{L} / \mathrm{W}$ ratio on the degree of delignification and kappa number (different letter $=$ significantly different; the same letter $=$ insignificantly different). 
indicated that the highest delignification selectivity was obtained from pulping with active alkali of $25 \%$ at an $\mathrm{L} / \mathrm{W}$ ratio of $6: 1$ (Fig. 3). At a lower alkaline charge, increasing the $\mathrm{L} / \mathrm{W}$ ratio decreased the delignification selectivity, probably due to the relatively faster depletion of hydroxide ions in the pulping liquor. Meanwhile, at higher alkali concentration, the hydrox$\mathrm{yl}$ ion concentration in pulping liquor was relatively constant, thus preventing the peeling reaction of cellulose from proceeding. Baptista et al.(2008) found that delignification selectivity reaches a maximum at particular active alkali and decreases with further alkaline charge. In soda-oxygen pulping of bagasse with the alkaline charge of $22-24 \%$, Yue et al.(2016) found

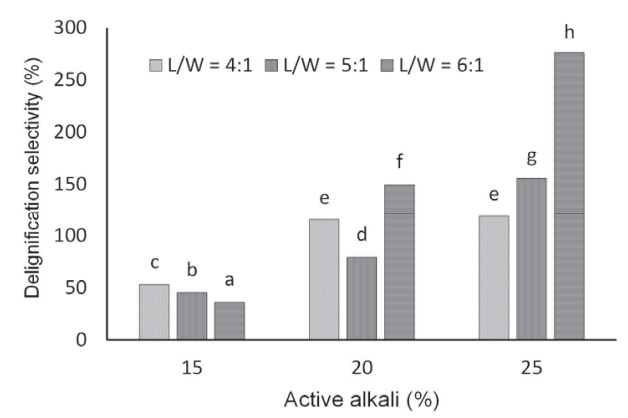

Fig. 3. The effect of active alkali and $\mathrm{L} / \mathrm{W}$ ratio on the delignification selectivity (different letter $=$ significantly different; the same letter $=$ insignificantly different).

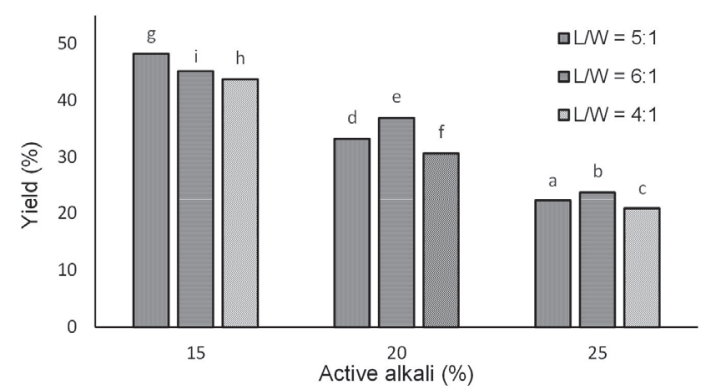

Fig. 4. The effect of active alkali and $\mathrm{L} / \mathrm{W}$ ratio on the pulping yield of torch ginger stem (different letter = significantly different; the same letter = insignificantly different). that the highest delignification selectivity was obtained at an alkaline charge of $23 \%$.

\subsection{Pulping yield}

Pulping yields revealed in Fig. 4 are the screened yield, which was calculated based on the oven-dry weight of pulp and chips. Except for the pulping with $15 \%$ active alkali, it can be seen that the yield of pulping tends to decrease with increasing active alkali. The inconsistency of yield trend of pulping at $15 \%$ active alkali by varying the $\mathrm{L} / \mathrm{W}$ ratio could be brought about by the possibility of redeposition of the degradation products of pulping reaction unto the pulp. Gustavssson (2007) concluded that redeposition of pulping reaction product occurred when using low $\mathrm{L} / \mathrm{W}$ ratio at low alkali concentration. The decrease of yield has been well known to be brought about by the degradation of lignin and part of the carbohydrates (Ma et al., 2012). The present results showed that active alkali, L/W ratio, and both treatments' interaction significantly influenced pulping yield. Further, Duncan's multiple range test indicated that the highest yield (48\%) was obtained from pulping with active alkali of $15 \%$ and $\mathrm{L} / \mathrm{W}$ ratio of $5: 1$, and the lowest (21\%) was with active alkali of $25 \%$ and $\mathrm{L} / \mathrm{W}$ ratio of $6: 1$. A high concentration of alkali in pulping liquor accelerates the delignification; however, it is also accompanied by increasing carbohydrates degradation (Santos et al., 2013), leading to the decreasing yield.

\section{CONCLUSION}

Torch ginger stem could be an excellent raw material for cellulose-based products, considering its high cellulose content (48.5\%). Its low lignin content (18.3\%) is promising for easy extraction of its cellulose, although the low S/G lignin ratio (0.70) needs to be considered in determining an appropriate pulping process. The decrease of the $S / G$ ratio upon pulping could also 
complicate the bleaching process when a high pulp brightness is required. Selective delignification of torch ginger stem occurred by using soda pulping with active alkali of $20-25 \%$ at an $\mathrm{L} / \mathrm{W}$ ratio of $6: 1$, resulting in pulp with a low kappa number of $5.11-2.78$ and a relatively moderate pulping yield. As indicated by the low kappa number obtained, the ease of torch ginger pulping could indicate that torch ginger a potential raw material for derivative products requiring delignification as pretreatments, such as bioethanol and nano cellulose. Simultaneously, the increase of its crystallinity after pulping could also complicate its conversion into bioethanol but could be an advantage for the production of nano cellulose.

\section{ACKNOWLEDGMENT}

This research was funded by the Directorate of Research and Community Service, Deputy for Strengthening Research and Development, Ministry of Research, Technology/National Research and Innovation Agency of the Republic of Indonesia with contract number 6546/IT3.L1/PN/2020 for the PMDSU Batch V program. We would also like to thank the Integrated Laboratory of Biomaterials at the Indonesian Institute of Science for using their laboratory facilities and the given scientific and technical assistance.

\section{REFERENCES}

Abdel-Aal, M.A. 2013. Effect of cooking time, active alkali concentration, and refining process on the pulping and papermaking properties of buttonwood residues (Conocarpus erectus L.). World Applied Science Journal 27(1): 1-9.

Abraham, E., Deepa, B., Pothan, L., Jacob, M., Thomas, S., Cvelbar, U., Anandjiwala, R. 2011. Extraction of nanocellulose fibrils from lignocellulosic fibers: A novel approach. Carbohydrate Polymers 86(4):
1468-1475.

Asosiasi Pengusaha Hutan Indonesia [APHI]. 2019. Roadmap Pembangunan Hutan Produksi 2019 2045. APHI, Jakarta, Indonesia.

Baptista, C., Robert, D., Duarte, A.P. 2008. Relationship between lignin structure and delignification degree in Pinus pinaster kraft pulps. Bioresource Technology 99: 2349-2356.

Browning, B.L. 1967. Methods of Wood Chemistry. Interscience, New York, USA.

Bušić, A., Marđetko, N., Kundas, S., Morzak, G., Belskaya, H., Šantek, M. I., Komes, D., Novak, S., Šantek, B. 2018. Bioethanol Production from Renewable Raw Materials and its Separation and Purification: A review. Food Technology and Biotechnology 56(3): 289-311.

Chang, Y.Q., Tan, S.N., Yong, J.W.H, Ge, L. 2012. Determination of Flavonoids in Costus speciosus and Etlingera elatior by Liquid ChromatographyMass Spectrometry. Analytical Letters 45: 345-355.

Chen, Y., Stevens, M.A., Zhu, Y., Holmes, J., Xu, H. 2013. Understanding of alkaline pretreatment parameters for corn stover enzymatic saccharification Understanding of alkaline pretreatment parameters for corn stover enzymatic saccharification. Biotechnology for Biofuels 6(1): 8.

Faix, O. 1991. Classification of lignins from different botanical origins by FT-IR spectroscopy. Holzforschung 45: 21-27.

FAO. 2009. State of the World's Forests. Global Demand for Wood Products. http://www.fao.org/3/i0350e/ i0350e02a.pdf

Foster, J. 2011. Former Hawaii 2011. Wiley Publishing, Hoboken, New Jersey.

Gümüskaya, E., Usta, M., Kirci, H. 2003. The effects of various pulping conditions on the crystalline structure of cellulose in cotton linters. Polymer Degradation and Stability 81(3): 559-564.

Gustavsson, M. 2007. The Significance of Liquor-to- 
Wood Ratio on the Reaction Kinetics of Spruce Sulphate Pulping. Master Thesis, Karlstads Universite, Sweden.

Hadar, Y. 2013. Sources for lignocellulosic raw materials for the production of ethanol. In: Varaco, I. (Ed). Lignocellulose Conversion. Springer; Heidelberg. pp. 21-38.

Iqbal, H.M.N., Kyazze, G., Keshavarz, T. 2013. Advances in the Valorization of Lignocellulosic Materials by Biotechnology: An Overview. BioResources 8(2): 3157-3176.

Isroi, Ishola, M.M., Millati, R., Syamsiah, S., Cahyanto, M.N., Niklasson, C., Taherzadeh, M.J. 2012. Structural changes of oil palm empty fruit bunch (OPEFB) after fungal and phosphoric acid pretreatment. Molecules 17: 14995-15012.

Iwamoto, S., Abe, K., Yano, H. 2008. The effect of hemicelluloses on wood pulp nano fibrillation and nanofiber network characteristics. Biomacromolecules 9(3): 1022-1026.

Jaafar, F.M., Osman, C.P., Ismail, N.H., Awang, K. 2007. Analysis of Essential Oils of Leaves, Stems, Flowers and Rhizomes of Etlingera Elatior (JACK) R. M. SMITH. The Malaysian Journal of Analytical Sciences 11(1): 269-273

Jang, J.H., Lee, S.H., Lee, M., Lee, S.M., Kim, N.H. 2017. Changes of micro-And nanoscopic morphology of various bioresources by different milling systems. Journal of the Korean Wood Science and Technology 45(6): 737-745.

Ji, X.-J., Huang, H., Nie, Z.-K., Qu, L., Xu, Q., Tsao, G.T. 2012. Fuels and Chemicals from Hemicellulose Sugars. Advances in Biochemical Engineering/ Biotechnology 128: 199-224.

Jiao, C., Xiong, J. 2014. Accessibility and morphology of cellulose fiber treated with sodium hydroxide. BioResources 9(4): 6504-6513.

Jo, J.S., Jung, J.Y., Yang, J.K. 2019. Effect of the growth period on bioethanol production from the branches of woody crops cultivated in short-rotation coppices. Journal of the Korean Wood Science and Technology 47(3): 360-370.

Khanjanzadeh, H., Park, B.D. 2020. Characterization of carboxylated cellulose nanocrystals from recycled fiberboard fibers using ammonium persulfate oxidation. Journal of the Korean Wood Science and Technology 48(2): 231-244.

Kikas, T., Tutt, M., Raud, M., Alaru, M., Lauk, R., Olt, J. 2014. Basis of energy crop selection for biofuel production: Cellulose vs. lignin. International Journal of Green Energy 13(1): 49-54.

Li, C., Cheng, G., Balan, V., Kent, M.S., Ong, M., Chundawat, S.P.S., Sousa, L.D., Melnichenko, Y.B., Dale, B.E., Simmons, B.A., Singh, S. 2011. Influence of physicochemical changes on enzymatic digestibility of ionic liquid and AFEX pretreated corn stover. Bioresource Technology 102(13): 6928-6936.

Li, Z., Jiang, Z., Fei, B., Cai, Z., Pan, X. 2014. Comparison of bamboo green, timber, and yellow in sulfite, sulfuric acid, and sodium hydroxide pretreatments for enzymatic saccharification. Bioresource Technology 151: 91-99.

Li, M., Pu, Y., Ragauskas, A.J. 2016. Current Understanding of the Correlation of Lignin Structure with Biomass Recalcitrance. Frontiers in Chemistry 4(45): 1-8.

Ma, X., Huang, L., Cao, S., Chen, Y., Luo, X., Chen, L. 2012. Preparation of dissolving pulp from bamboo for textile applications. Part 2. Optimation of pulping conditions of hydrolyzed bamboo and its kinetics. BioResources 7(2): 1866-1875.

Mai, C.W., Wong, S.Y., Tan, E.L., Balijepalli, M.K., Pichika, M.R. 2009. Antiproliferative and Apoptotic Studies of the Standardised Extracts of Etlingera elatior on Human Colorectal Carcinoma Cells. Malaysian Journal of Chemistry 11(1): 136-142. Maimulyanti, A., Prihadi, A.R. 2015. Chemical composition, 
phytochemicals, and antioxidant activity from the extract of Etlingera elatior flower from Indonesia. Journal of Pharmacognosy and Phytochemistry 3(6): 233-238.

Marques, G., Rencoret, J., Gutierrez, A., Rio, J.C.D. 2010. Evaluation of the chemical composition of different non-wood plant fibers used for pulp and paper manufacturing. The Open Agriculture Journal 4: 93-101.

Maryana, R., Ma'rifatun, D., Wheni, A., Satriyo, K.W., Rizal, W.A. 2014. Alkaline pretreatment on sugarcane bagasse for bioethanol production. Energy Procedia 47: 250-254.

Matthews, J.F., Himmel, M.E., Crowley, M.F. 2011. Conversion of cellulose $\mathrm{I}_{\alpha}$ to $\mathrm{I}_{\beta}$ via a hightemperature intermediate (I-HT) and other cellulose phase transformations. Cellulose 19(1): 297-306.

Maurya, D.P., Singla, A., Negi, S. 2015. An overview of key pretreatment processes for biological conversion of lignocellulosic biomass to bioethanol. 3 Biotech 5: 597-609.

Min, D., Yang, C., Shi, R., Jameel, H., Chiang, V., Chang, H. 2013. The elucidation of the lignin structure effect on the cellulase-mediated saccharification by genetic engineering poplars (Populus nigra L. 3 Populus maximowiczii A.). Biomass Bioenergy 30: 1-6.

Moradbak, A., Tahir, P.M., Mohamed, A.Z., Halis, R. 2016. Alkaline sulfite anthraquinone and methanol pulping of bamboo (Gigantochloa scortechinii). BioResources 11(1): 235-248.

Moreno, G., Ramirez, K., Esquivel, M., Jimenez, G. 2018. Isolation and Characterization of Nanocellulose Obtained from Industrial Crop Waste Resources by Using Mild Acid Hydrolysis. Journal of Renewable Materials 6(4): 362-369.

Nieschlag, H.J., Nelson, G.H., Wolff, J.A., Perdue, R.E. 1960. A search for new fiber crops. TAPPI 43(3): 193-201.
Park, S.H., Jang, J.H., Wistara, N.J., Hidayat, W., Lee, M., Febrianto, F. 2018. Anatomical and physical properties of Indonesian bamboos carbonized at different temperatures. Journal of the Korean Wood Science and Technology 46(6): 656-669.

Pennells, J., Godwin, I.D., Amiralian, N., Martin, D.J. 2020. Trends in the production of cellulose nanofibers from non-wood sources. Cellulose 27(2): 575-593.

Purnawati, R., Febrianto, F., Wistara, I.N.J., Nikmatin, S., Hidayat, W., Lee, S.H., Kim, N.H. 2018. Physical and chemical properties of kapok (Ceiba pentandra) and balsa (ochroma pyramidale) fibers. Journal of the Korean Wood Science and Technology 46(4): 393-401.

Rahnama, N., Mamat, S., Shah, U.K.M., Ling, F.H., Rahman, N.A.A., Ariff, A.B. 2013. Effect of alkali pretreatment of rice straw on cellulase and xylanase production by local Trichoderma harzianum SNRS3 under solid state fermentation. BioResources 8(2): 2881-2896.

Ruiz-Aquino, F., Ruiz-Ángel, S., Feria-Reyes, R., Santiago-García, W., Suárez-Mota, M.E., RutiagaQuiñones, J.G. 2019. Wood chemical composition of five tree species from Oaxaca, Mexico. BioResources 14(4): 9826-9839.

Salehian, P., Karimi, K., Zilouei, H., Jeihanipour, A. 2013. Improvement of biogas production from pine wood by alkali pretreatment. Fuel 106: 484-489.

Santos, R.B., Jameel, H., Chang, H., Hart, P.W. 2013. Impact of lignin and carbohydrate chemical structures on degradation reactions during hardwood kraft pulping processes. BioResources 8(1): 158-171.

Shafaei, E., Ahmad, I., Adnan. 2011. The wonder of kantan: using torch ginger fibres to produce fine art papers. SPAFA Journal 21(3): 17-25.

Studer, M.H., DeMartini, J.D., Davis, M.F., Sykes, R.W., Davison, B., Keller, M., Tuskan, G.A., Wyman, C.E. 2011. Lignin content in natural Populus variants affects sugar release. Proceedings of the 
National Academy of Sciences 108(15): 6300-6305. Suryanto, H., Marsyahyo, E., Irawan, Y.S., Soenoko, R. 2014. Effect of alkali treatment on crystalline structure of cellulose fiber from mendong (Fimbristylis globulosa) straw. Key Engineering Materials 594-595: 720-724.

TAPPI. 1997. TAPPI Test Methods. TAPPI Press. Atlanta

Tsutsumi, B.Y., Kondo, R., Sakai, K., Imamura, H. 1995. The difference of reactivity between syringyl lignin and guaiacyl lignin in alkali systems. Holzforschung 49(5): 423-428.

Ververis, C., Georghiou, K., Christodoulakis, N., Santas, P., Santas, R. 2004. Fiber dimensions, lignin, and cellulose content of various plant materials and their suitability for paper production. Industrial Crops and Products 19(3): 245-254.

Wada, M., Hori, R., Kim, U., Sasaki, S. 2010. X-ray diffraction study on the thermal expansion behavior of cellulose $\mathrm{I} \beta$ and its high-temperature phase. Polymer Degradation and Stability 95: 1330-1334. Wada, M., Okano, T. 2001. Localization of $\mathrm{I} \alpha$ and $\mathrm{I} \beta$ phases in algal cellulose revealed by acid treatments. Cellulose 8: 183-188.

Wang, X., Jia, Y., Liu, Z., Miao, J. 2018. Influence of the lignin content on the properties of poly(lactic acid)/lignin-containing cellulose nanofibrils composite films. Polymers. 10: 1-14.
Wistara, N.J., Carolina, A., Pulungan, W.S., Emil, N., Lee, S.H., Kim, N.H. 2015. Effect of tree age and active alkali on kraft pulping of White Jabon. Journal of the Korean Wood Science and Technology. 43(5): 566-577.

Xiao, L.P., Shi, Z.J., Xu, F., Sun, R.C. 2012. Characterization of Lignins Isolated with Alkaline Ethanol from the Hydrothermal Pretreated Tamarix ramosissima. BioEnergy Research 6(2): 519-532. Yanti, H., Syafii, W., Wistara, N.J., Febrianto, F., Kim, N.H. 2019. Effect of biological and liquid hot water pretreatments on ethanol yield from mengkuang (Pandanus artocarpus Griff). Journal of the Korean Wood Science and Technology 47(2): 145-162. Yoo, C.G., Yang, Y., Pu, Y., Meng, X., Muchero, W., Yee, K.L., Thompson, O.A., Jr., M,R. Bali, G., Engle, N.L., Lindquist, E., Singan, V., Schmutz, S., DiFazio, S.P., Tschaplinski, T.J., Tuskan, G.A., Chen, J.G., Davison, B., Ragauskas, A.J. 2017. Insights of biomass recalcitrance in natural Populus trichocarpa variants for biomass conversion. Green Chemistry 19(22): 5467-5478.

Yue, F., Chen, K.L., Lu, F. 2016. Low temperature sodaoxygen pulping of bagasse. Molecules 21(85): 1-12.

Zhu, J., Wan, C., Li, Y. 2010. Enhanced solid-state anaerobic digestion of corn stover by alkaline pretreatment. Bioresource Technology 101: 7523-7528. 